\title{
Taiwan's Foreign Economic Relations \\ with Developing Nations: A Case Study \\ of Its Ties with Palau
}

\section{Eric Harwit}

Since the world began shifting its diplomatic recognition and economic ties away from the Republic of China (Taiwan), and toward the People's Republic of China ${ }^{1}$ in the r97os, the Taiwan government has solicited political and economic support from smaller nations. As of early 2000, Taiwan had formal relations with some twenty-nine countries, and most of these ties were cemented with economic or other significant aid.

In seeking to broaden its international influence, Taiwan's foreign policy has focused on both the large, developed nations that have probably irrevocably switched recognition to China, and to less developed, often smaller states. These smaller countries can offer full diplomatic ties, as well as occasional voting support on important issues in international forums such as the United Nations. With Taiwan's legitimacy as an independent entity constantly challenged by China, every foreign diplomatic relation is counted as a significant achievement. In addition to these political motivations, these countries are potentially lucrative foreign investment targets. Taiwan's foreign aid is often the key to winning a new embassy.

In earlier research, Gerald Chan examined Taiwan's politically motivated "southward policy" of courting mainly larger countries in Southeast Asia, and Chen Hurng-yu looked at Taiwan's economic and investment ties to several of Asia's developing nations (Chan 1996; Chen 1994). Most of the target nations, such as Malaysia, the Philippines, and Vietnam, generally benefitted from the inflow of foreign capital, though it constituted a relatively small part of their overall economies. Even with no diplomatic relations in this part of the world, Taiwan gains some

The Contemporary Pacific, Volume I2, Number 2, Fall 2000, 465-479

(C) 2000 by University of Hawai $i$ Press 
implicit political clout and moral support from its economic ties with the countries of Southeast Asia.

Taiwan's more successful diplomatic efforts have come in the least developed parts of the world. Ian Taylor has focused on its competition for recognition in African nations, where "dollar diplomacy" has won it recognition by eight states (I998). Karl Fields has taken a wider view of this economic statesmanship and explored the investment policies of Taiwan's ruling Nationalist Kuomintang party in several parts of the world (I998). However, few of these or other works focus on the use of Taiwan's aid or investment in the small, developing states.

The results of Taiwan's investment expansion in developing nations have several implications for ties with other regions of the world, including Pacific Island states. First, the movement allows it to diversify its economic relations away from a growing number of investment projects in neighboring China, which could be tempted to use the resulting leverage for economic or political manipulation. As noted, Taiwan also stands to improve ties with the target nations, even if diplomatic relations remain informal. However, many developing countries have poor infrastructure, and find absorbing funds difficult. On balance, the political pay-off to Taiwan may outweigh any real economic gain for its investors, or even for some of the recipient countries.

This essay extends the examination of Taiwan's efforts to develop economic and political ties with developing states, and focuses on the recently independent nation of Palau. Palau has strengthened its economic and political relations with Taiwan significantly since 1994, when it shed its status as a United Nations trust territory administered by the United States. Finally, in late December I999, Palau extended official diplomatic recognition to Taiwan. Here I examine strategies the Taiwanese government and quasi-private industry have used to solidify ties with Palau, and the effects these actions have had on Palau's economic, as well as social and political, development.

I begin with a brief look at Taiwan's relations with other Pacific Island states, and touch on the ways it has fostered bonds with the small nations. I then turn to the recent history of Taiwan's move into Palau, and the effects its strategy has had there. In examining Taiwan's efforts, I consider both beneficial and detrimental effects of its investment in Palau. I conclude with an assessment of current Taiwan-Palau economic ties, and include lessons for Taiwan, Palau, and other potential clients of Taiwan's recent foreign-economic-policy drive among the smaller developing nations of the world. 


\section{Taiwan's Relations in the Pacific Islands}

As of early 2000, Taiwan had formal diplomatic relations with five Pacific Island states: Solomon Islands, Tuvalu, Nauru, the Marshall Islands, and Palau. Over the last three decades, Taiwan has competed with China for recognition among many of the newly independent states in the region, employing a number of strategies. ${ }^{2}$

In the 1970s, both China and Taiwan focused attention on nations such as Fiji, Tonga, Sāmoa (formerly Western Sāmoa), and Solomon Islands. Taiwan achieved some early success, opening a trade office in Fiji in 1971, and establishing nonresident diplomatic ties with Tonga and Sāmoa in 1972. Following a series of exchanged visits by Taiwan and Pacific Island leaders, ties were established with Nauru, Tuvalu, and Solomon Islands at various times in the late 1970s and early 1980s. In 1975, however, Taiwan broke relations with Sāmoa following that country's switch to China.

In October 1998, Tonga announced that it was switching its recognition from Taiwan to China. However, a month later the Marshall Islands restored the balance when it established full diplomatic ties with Taipei. For a short period in mid-1999, Taiwan's allies in the Pacific included Papua New Guinea, but the recognition was revoked in less than a month by a new prime minister.

Taiwan's strategies for developing ties have included more than reciprocal visits. In Fiji, for example, it offered cash grants, as well as technical and developmental assistance; Fiji, however, maintains official ties with China. In Tonga, the Taiwanese funded a stadium construction project, and in Solomon Islands they built a hospital. In October 1999, following establishment of diplomatic ties, Taiwan gave the Marshall Islands \$2 million to purchase two German airplanes (HA, IO Oct I999, A2). ${ }^{3}$ In December 1999, Palau extended its ties to Taiwan.

Despite some success for Taiwan, many of the small Pacific states have played the two Chinas off against each other in order to obtain the maximum economic and political benefit. To show its interest in the region, the Beijing government has made pledges of agricultural assistance to Sāmoa and helped construct Vanuatu's new parliament building. In sum, the Pacific Island nations have used their not insubstantial leverage of diplomatic recognition, along with an implied favorable $\mathrm{UN}$ vote on issues of concern to both Chinas, to win economic favors from each of the two claimants to Chinese rule. The pattern is one that the newly independent Republic of Palau would be expected to follow. 


\section{Palau's Economic Ties with Asia}

Palau's recent history has influenced both its political and its economic ties with the major economic powers of the Pacific rim. ${ }^{4}$ Japan and the United States, both former colonial powers in Palau, have played key roles in the nation's development, although Taiwan's influence has increased dramatically in recent years.

In the I980s, the United States and Palau negotiated a Compact of Free Association, an agreement that gives the US military rights in Palau for fifty years, in exchange for some $\$ 627$ million paid over the agreement's first I5 years (Osman I997, IO). Palau, however, maintains control over its own domestic and foreign policy. The compact took effect in 1994, the same year Palau gained independence and jointed the United Nations. The following year, the new nation received nearly $\$ 250$ million in frontloaded compact payments, though the allocation fell to about \$ I 20 million in I996, and to some \$I5 million in I997, with similar annual income set for the following twelve years. As payments decrease over later years, and its military interests in the region weaken, the United States' involvement in the country's affairs seems destined to decline.

Palau's proximity to Asia makes it a natural candidate for interest from wealthy neighbors to the north. The nation is approximately five hours by air from Tokyo, and three-and-a-half hours from Taiwan. By the I970s, Palau was already being eyed as a major potential tourist attraction and investment site.

Early moves from Asian investors came after the United States lifted restrictions on foreign investment in 1974. Japanese who had been part of the civilian workforce during the Japanese administration in the r930s visited Palau to see how they might resume their economic involvement. Kazuhiko Kohno represented the Tokyu Land Corporation, which decided to build a world-class resort to help spur the island territory's tourist industry. Tokyu spent the mid-I970s acquiring land-use rights for what would become the Palau Pacific Resort. At the time, Tokyu, like other potential investors in Palau, had to follow rules created by an indigenous Foreign Investment Board; the board's authority succeeded that of the region's US-appointed high commissioner, who previously had the authority to approve foreign participation. But the board reportedly followed the desires of Palau's president (first elected in I980), and financial incentives rather than projects' merits may have influenced the approval process at times. The luxury resort cost some \$25 million to build and took 
nearly eight years to complete, but it opened to burgeoning tourist interest in December I984. As the tourist industry began to take off in Palau, other Japanese investors arrived to emulate the early hotel's example. Table I gives the numbers and origins of tourists arriving in Palau over the past decade.

Early interest from Taiwan investors also came in the mid-r980s, as independence appeared on the horizon and tourist interest grew. Taiwanese who saw the rising potential invested in the medium-standard Palau Hotel, which cost \$ I million to build. For the following decade, though, most other hotel projects were initiated by Japanese investors, and there was relatively little interest from Taiwan businesses.

One key problem in expanding foreign investment was the delineation of property rights. Following the long history of colonization by the Spanish, Germans, Japanese, and Americans, land ownership rights had become unclear. However, one rule remained firm: only Palau citizens

Table I. Tourist Arrivals in Palau by Origin, I986-1998

\begin{tabular}{rrrrrrrrrr}
\hline & USA & Japan & Philippines & Europe & Taiwan & Korea & Others & Total \\
\hline 1986 & 3,747 & 6,567 & 1,578 & 568 & - & - & 1,193 & 13,653 \\
1987 & 4,205 & 6,924 & 1,915 & 916 & - & - & 2,735 & 16,695 \\
1988 & 4,821 & 10,818 & 2,194 & 1,121 & - & - & 3,721 & 22,675 \\
1989 & 6,060 & 11,633 & 2,764 & 1,105 & - & - & 4,443 & 26,005 \\
1990 & 6,440 & 13,212 & 3,528 & 1,674 & - & - & 7,992 & 32,846 \\
1991 & 6,411 & 14,529 & 4,073 & 1,202 & - & - & 6,485 & 32,700 \\
1992 & 8,032 & 17,021 & 4,032 & 1,527 & - & - & 5,505 & 36,117 \\
1993 & 7,861 & 18,554 & 3,622 & 1,722 & - & - & 8,738 & 40,497 \\
1994 & 9,700 & 17,493 & 3,554 & 2,207 & 6,126 & 1,221 & 3,772 & 44,073 \\
1995 & 9,846 & 21,052 & 3,199 & 2,508 & 11,163 & 1,823 & 3,638 & 53,229 \\
1996 & 9,955 & 22,619 & 3,838 & 2,870 & 23,309 & 2,074 & 4,665 & 69,330 \\
1997 & 10,481 & 20,507 & 2,955 & 1,521 & 31,246 & 1,782 & 6,951 & 73,719 \\
1998 & 12,487 & 21,571 & na & na & 18,503 & 545 & na & 64,194 \\
\hline
\end{tabular}

Note: na $=$ not available.

Sources: Figures for 1986-1996 are from Osman (1997, 20). The 1997 and 1998 figures for USA, Japan, Taiwan, Korea, and totals are from Tia Belau (22 Jan I999, I, 9; 6 Feb I999, 6); other I997 figures are projected from Osman I997, therefore totals do not add. 
could own land in the republic. Citizenship was limited to those who could prove Palauan ancestry, but foreigners could lease land for periods of up to fifty years.

In recent years, Taiwan has shown renewed interest in Palau. Taiwan tourism has become a major part of Palau's visitor industry, and in 1996 the number of Taiwanese tourists exceeded those from Japan for the first time. The progress of this interaction is outlined in the following section.

\section{Taiwan's Overtures: Tourism and Investment in Palau}

By the early I990s, it was clear to the Taiwan government that Palau would soon join the list of small island nations that might extend diplomatic relations to Taiwan. ${ }^{5}$ Not only could Palau add to the list of official diplomatic representatives in Taipei, but its UN membership and other international participation could add more votes to initiatives favored by Taiwan and the Kuomintang.

Some eighty delegates from Taiwan attended Palau's independence ceremony on I October I994. Their arrival followed the creation of an "agricultural mission" that apparently had support from the Taiwan government (TB, 3I Dec I994, 3). Soon after, Palau's President Kuniwo Nakamura accepted an invitation to make a three-day trip to Taipei in March I995. His visit was notable for the warm reception he received from Taiwan's President Lee Teng-Hui ( $P G$ 27, 3 I March I995, 7). In July of the same year, a delegation of twenty-seven Taiwan businesspeople visited Palau for further talks (PG 3I, 3I July I995, 2).

The early discussions were facilitated by Palau's rather liberal policy of allowing Taiwan citizens to obtain visas on entry to the country. This made Palau one of the few areas in the world that citizens of Taiwan could visit while avoiding the tedious process of approaching a foreign representative's office and waiting long periods for permission to enter. In April I995, Continental Micronesia doubled the number of its flights from Taipei to Koror to accommodate the rapidly growing number of tourists ( $T B$, 20 May I995, 4). Initial enthusiasm for these ties ran high among Palauans, who believed the Taiwanese would supplement the large number of Japanese tourists who had been visiting the islands since the I970s for diving and vacation.

At about this time, tourism assumed a more important place in the minds of the leaders of the newly independent republic. Although the American compact payments amounted to a fantastic windfall, future 
years would see diminished income. Tourism was seen as an industry that could fill the gap of declining revenues. By I992, the sector represented some ro percent of Palau's overall gross domestic product. Fishing still accounted for about 29 percent, with government service (I 6 percent) and construction ( 8 percent) making up the other main segments of the economy (Osman I997, 9).

As Continental moved to expand service, Taiwan's own domestic carrier, Far East Air Transport, began talks in May I995 to establish charter flights to Palau. The airline is reportedly owned 56 percent by the China Development Corporation, the venture-capital company of the Kuomintang (TB, I2 Aug I995, I, IO). After only two months of talks, Far East Air began flying to the island republic in July, with corporation chairman Liu Tai-ying arriving on the maiden flight ( $P G$ 3 I, 3 I July I995, 2). The service, initially called Air Palau, started with two flights a week, and soon put an end to Continental's service. The next month, President Nakamura made another visit to Taipei to discuss the ongoing tourist interest in Palau.

Palau appeals to Taiwan tourists for several reasons. In addition to receiving a visa on arrival, the flight to Palau is relatively short. Air tickets cost about Io,000 New Taiwan dollars (NT, equal to about us\$300), and tour packages start from NT $\$ 20,000$. Far East Air promoted the travel as a weekend escape for young people too busy to travel greater distances. Table 2 shows the number of passengers on Far East Air flights in the service's first three years of operation.

The growing number of Taiwanese visitors helped build a special relation between Palau and Taiwan. For Far East Air and Taiwan travel agencies the business also proved profitable. A representative of the airline interviewed in 1998 felt the number of visitors from Taiwan could eventually reach fifty thousand.

One of the problems in attracting more Taiwan tourists to Palau has been the shortage of comfortable hotel space to meet demand. Only the Palau Pacific Resort has met high international standards, and in the mid I990s the total number of rooms available throughout the republic was fewer than seven hundred.

In January 1995, Dr David Chen, president of the Asia Pacific section of the Kuomintang's Central Investment Holdings Company, visited Palau to discuss construction of a new world-class hotel. His partner in the project was Alan Seid, a delegate from Koror in the Palau central government and chairman of the House Ways and Means Committee. In August 1995 


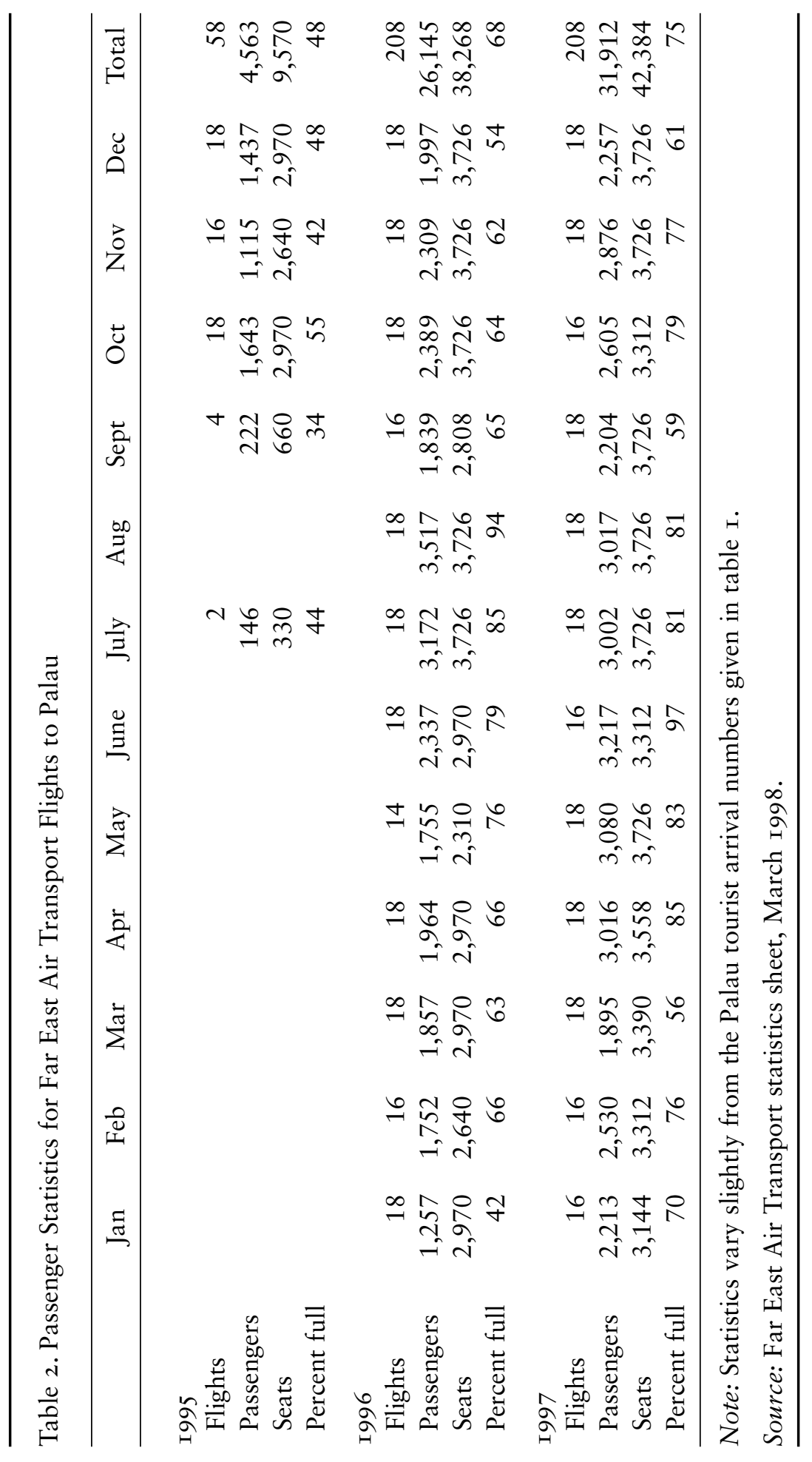


the two reached an agreement to build the Palasia Hotel, with joint-venture ownership. The Taiwan side held 80 percent ownership, and 20 percent went to their Palauan partners. The hotel was built on Seid's land in Koror to avoid the problems associated with property purchases by foreigners. The company made rapid progress with construction, though virtually all of the materials had to be imported. Most of the labor was provided by as many as two hundred Chinese workers sent to Palau for the project. The company also invested in a pig farm, to guarantee a stable supply of food for the hotel's mainly Taiwanese guests.

The six-floor, I65-room hotel-the tallest building in the island republic-opened in August I998, under the management of the Honolulubased Outrigger group, with daily room charges ranging from $\$ \mathrm{I} 82$ to as high as $\$ 778$ for a suite in peak season. However, even at these rates, it is unclear how long it will take the Taiwanese company to recoup its $\$ 40$ million investment, which works out at about $\$ 250,000$ per room.

Others in the Kuomintang business leadership joined in to support the large hotel project and to reinforce Taiwan-Palau friendship. Liu Tai-ying presided over a ceremony in the fall of 1995 to officially announce the Palasia construction, and to pledge the China Development Corporation's support for "projects ranging from fishery, tourism, banking, airline industry [to] infrastructure" (TB, 7 Oct I995, 6). In October I995, a newly organized Taiwan-Palau Cultural, Economic, and Trade Interchange Association announced it was donating \$50,000 to fund Palau's independence anniversary celebrations ( $P G$ 34, 3 I Oct I995, 3). Later, in early 1996, the association, led by chairman Gino Chung-Chu Chen, broke ground for a joint construction project known as the Palau Empire Entertainment World. The project's goal was construction of a $\$ 70$ million, 600-house resort village on Palau's large northern island, Babeldaob (TB, 6 April I996, I, 8). By mid-June I996, nearly all of the houses had reportedly already been purchased by Taiwan investors (TB, I7 June I996, I3). However, the project's fifty-year lease, renewable for another fifty years, incited some local political leaders to protest the foreign-invested development, and in 1999 the courts declared the lease void. With the association's offices now closed, it seems unlikely that the project will ever be built-much to the chagrin of investors in Taiwan who reportedly paid $\$ 75,000$ for property in the resort (Shuster 2000).

Another Taiwanese-funded real estate project, the \$50 million Hung Kuo Resort, broke ground in August 1998. With some 407 rooms, this luxury resort near Koror is much bigger than the Palasia, and includes 
Delegate Alan Seid's investment of $\$ 3.2$ million (TB, 6 June 1998,$3 ; 29$ Aug 1998). Other Taiwan-invested projects included the Ever Fortune Development Company's plan to build two water system projects valued at a total of $\$ 520,000$ (TB, I7 Nov I996, I). President Nakamura made another trip to Taiwan in May 1996 to open an "honorary consulate" and attend President Lee's inauguration as first elected president of Taiwan, and it seemed the country's initiative to cultivate good ties was beginning to bear diplomatic fruit. But Palau had pointedly avoided recognizing either Taiwan or China; this was one of many problems of Taiwan-Palau ties that have come to light in recent years.

\section{Problems of Tourism and Investment}

Early controversy between Taiwan and Palau arose in late 1995. Some unscrupulous investors sought to develop a scheme for circumventing Palau's strict landownership and citizenship rights. The republic's Commerce and Trade minister had to deny allegations of his own involvement in a plan to sell Palauan citizenship to Taiwanese, a status that was supposed to allow the Taiwanese participants to purchase and develop land (TB, 2I Oct I995, I, IO). Advertisements had appeared in Taiwan newspapers, falsely implying that investors contributing several hundred thousand dollars to a real estate project in Palau could obtain permanent residence after one year, and citizenship after five years (TB, 23 Sept I995, I). Such a scheme would appeal to citizens of Taiwan, who often find international travel cumbersome using a Taiwan passport.

Meanwhile, Taiwanese tourism in Palau was beginning to create separate problems for relations with Taiwan. Conversations with Palauan tourist officials reveal frustration with the environmental impact of rapidly rising Taiwan visitor numbers. Unlike Japanese or western tourists, many Taiwanese visitors apparently cannot swim. On visits to colorful coral reef areas, some tourists walk on (rather than swim over) the delicate coral animals and damage them. The Palauans seem to have developed (whether justified or not) a prejudice in favor of Japanese tourists, who they believe are more respectful of the environment, and against the Taiwanese, who are perceived as less considerate.

Problems of adverse environmental impact by the new wave of tourism could grow in the future. A Far East Air representative noted that future tourists to Palau may expect more entertainment than snorkeling and scuba diving - they may want to see parasailing and other water sports 
available to enhance their Pacific Island vacations. This development would follow the path of other vacation spots in the region, such as Guam. In early I998, Palau also was negotiating to introduce a ship-based casino (NST, I 2 March I998, I9). The addition of these attractions might boost tourist numbers, but would add to the environmentally unfriendly effects of tourism.

Other Palauans complained about the effect of Taiwan's tourism on the domestic service sector. One travel agent noted that the inexpensive tours from Taiwan had cut group tour prices from about $\$ 250$ for a twoday hotel and city tour package to only about $\$_{\text {I }}$ O. Some local restaurants also have become the exclusive domain of Taiwan tour operators and other foreign investors. Foreign representatives can lend money to create joint operations with Palauan "front" organizations that allow the outside investors to skirt Foreign Investment Board regulations. Taiwan tourists are guided to the quasi-joint-venture establishments, allowing the Taiwan investors to reap profits from their compatriots. This leaves less money to support the Palauan-owned restaurants.

Other Taiwan interests have been accused of unethical behavior. The Ever Fortune Development Corporation, which won bids to build two water systems, may have skirted import tax rules to bring construction equipment to Palau in I995 (TB, I7 Nov I996, I3). A Taiwan fishing company, Ting Hong, was accused of trying to bribe two members of Palau's Foreign Investment Board to obtain an investment permit ( $T B, 22$ Feb I997, 3). And in early I998, the Far East Air Transport airport desk in Palau was reportedly distributing a leaflet promoting a massage parlor (TB, 25 April I998, 3).

On the diplomatic front, success for Taiwan's initiative long remained elusive. In May 1997, President Nakamura led a delegation of Palauan leaders to Beijing, to a warm welcome from the mainland Chinese leadership ( $P G$ 53, May-June I997, 4). Central Investment Holding Company's investors felt "betrayed" by this move, and their disappointment was most likely shared by others in the Taiwan government. In May I998, a second Palau delegation returned from Beijing with a pledge of \$500,000 toward the regional "Micro Games" athletic competition (TB, 23 May I998, I0), and in late 1999 China donated $\$ 400,000$ worth of luxury vehicles to aid Palau's hosting of the regional South Pacific Forum (TB, I3 Sept I999, 3). For tourism purposes, though, China was less useful, as fewer than a thousand of its citizens visit Palau each year.

According to officials in Palau, the republic purposely was playing off 
the two Chinas, and did not want to repeat the "mistake" of other Pacific Island nations by recognizing one or the other. The Marshall Islands briefly had relations with both Taiwan and China in late 1998, but China cut ties after just a few weeks.

Taiwan's early hopes may have rested on Palasia investor Alan Seid, who was a potential presidential candidate in the 2000 election $(T B, \mathrm{I} 2$ Sept I998). Other scholars in Palau, however, noted that subtle pressure by the country's traditional ally, the United States, might have prevented Palau from choosing to recognize Taiwan. Finally, however, on 30 December I999, the Palau government decided to extend formal diplomatic recognition to Taiwan.

\section{Future Development of Taiwan-Palau Ties}

Though Taiwan's battle for diplomatic recognition from Palau finally bore fruit, the future of the Asian investment strategy seems murky. By early I998, Taiwan tourism to Palau had begun to slow, as illustrated in Table I. The loss in value of the New Taiwan dollar against the US dollar made Palau more expensive for Taiwanese visitors. ${ }^{6}$ Alternative travel destinations, such as Thailand or the Philippines, were more attractive, as their currencies had fallen as much as or even more than Taiwan's. Far East Air Transport itself had begun charter flights to Subic Bay in the Philippines and noted that these trips represented competition for Palau vacation travel. Central Investment Holdings noted that some flights to Palau in the first half of I998 had as few as twenty passengers, though Far East Air had begun flights from both Taipei and Kaohsiung to the Pacific island. In mid-I998, however, Fare East Air cut the number of its weekly flights from four to two.

In addition to exchange-rate problems, various taxes imposed by the Palau government affected tourist attitudes toward their Palau vacation. Airport departure tax, for example, was a rather high \$20. Central Investment Holdings asserted that taxes were also charged on tourists visiting the coral reefs around Palau's Rock Islands. Growing traffic problems and concerns for personal safety on the streets of Koror also make Palau a less attractive vacation destination.

Despite the pessimistic forecast for the Taiwan-built tourist industry, Taiwan's investors had not yet conceded defeat in their move to Palau. Central Investment Holding Company's Dr Chen suggested the textile and fishing industries could supplement the republic's economic develop- 
ment, and noted that Taiwan corporations had great experience in these areas and were exploring opportunities for investment. Other possibilities for cooperation were for construction of monuments to World War II battles, and for improving accommodations in islands remote from the capital city, Koror. These last projects, though, were again dependent on the continued growth of tourism. Overall, investments backed by Kuomintang business interests showed mixed results as of early 1998. Though Far East Air appears to be making profits, Central Investment Holdings' Palasia would seem to be in a bind if the tourism industry faltered.

Taiwan's initial strategy for cementing ties with Palau seemed at first to be faulty. Palau was content to court both Chinas, and apparently did not want to cement relations with Taiwan no matter how many economic tools the Taiwanese might employ. In September 1999, for example, a vote to put Taiwan's membership in the United Nations on the organization's agenda failed, though it was supported by the Marshall Islands and Solomon Islands. Palau (and newly admitted Nauru) did not support Taiwan's bid (IHT, I7 Sept I999, Iо). ${ }^{7}$

For the Palauans, Taiwan's efforts had both positive and negative results. Tourism and construction investments set the foundation for an economy that could withstand the decline of American compact funds. The Taiwanese also seemed interested in developing other industries, such as fishing.

For Palau to truly benefit from these capital flows, however, the process would require more thorough regulation by the island republic's government. Projects agreed to only after promises of large investment dollars or quasi-legal alliances with local businessmen could prove ill-suited for the economy's long-term development needs. Improved government oversight of foreign investment could help remedy these problems. But, if Palau's diplomatic dance between Taiwan and China were to eventually alienate Taiwanese investors, all of the projects could disappear quite quickly, leaving both Palauans and Taiwanese with little to show for several years of effort. Though it is unclear as of this writing why Palau extended its recognition, economic and political pressure from Taiwan was probably a key factor in motivating the choice of that country over China. It is also unclear, however, whether the March 2000 election of new Taiwan President Chen Shui-bian, leader of the KMT-opposition Democratic Progressive Party-will affect Taiwan's future ties with Palau and other Pacific Island states.

Other developing nations may learn from Palau's example. Taiwan is 
eager to find diplomatic recognition where it can, and investment and aid dollars stand to follow political relations. But Taiwan's motivation lies in improving its own standing in the world, rather than in advancing the interests of small nations. Palau's experience tells nations that easy money may follow ties with Taiwan, but it is up to the developing country to use it wisely. Furthermore, the game of trying to balance China and Taiwan against each other to obtain benefit from both cannot be played indefinitely.

I wish to thank Dr Terence Wesley-Smith and two anonymous reviewers for comments on early drafts of this paper. Thanks also to Dr Wali Osman of the Bank of Hawaii for his kind help in introducing interviewees in Palau, and Dr Edgar Porter of the University of Hawai' i for helping arrange interviews in Taiwan.

\section{Notes}

I To avoid confusion, throughout this article the Republic of China is referred to as Taiwan, and the People's Republic of China simply as China.

2 Some of the information in the following section is based on an article by Biddick (I989).

3 In mid-I998, Solomon Islands requested \$ Ioo million from the visiting premier of Taiwan, but this sum apparently exceeded Taiwan's willingness to provide aid (PIR, July I998).

4 Unless otherwise noted, information in the following section is derived from interviews conducted in Palau in November 1997.

5 Unless otherwise noted, the following information is based on interviews held with Taiwan business representatives in March 1998.

6 Palau uses the US dollar as its national currency.

7 Tuvalu is not currently a UN member state.

\section{References}

Biddick, Thomas V

I989 Diplomatic Rivalry in the South Pacific: The PRC and Taiwan. Asian Survey August: $800-8$ I 5 .

Chan, Gerald

I996 Sudpolitik: The Political Economy of Taiwan's Trade with Southeast Asia. The Pacific Review 9 (I): 96-II3. 
Chen Hurng-yu

I994 Taiwan's Economic Relations with Southeast Asia. In Taiwan in the Asia-Pacific in the I990s, edited by Gary Klintworth, I2 I-I33. Syd-

Fields, Karl J ney: Allen \& Unwin.

1998 кмт, Inc: Party Capitalism in a Developmental State. JPRI Working Paper 47. Cardiff, CA: Japan Policy Research Institute.

Hezel, Francis X

1995 Strangers in Their Own Land: A Century of Colonial Rule in the Caroline and Marshall Islands. Pacific Islands Monograph Series, I3. Honolulu: Center for Pacific Islands Studies and University of Hawai'i Press.

HA, Honolulu Advertiser. Daily.

IHT, International Herald Tribune. New York. Daily.

NST, New Straits Times. Singapore. Daily.

Osman, Wali

I997 Republic of Palau: Economic Report. Honolulu: Bank of Hawaii.

PIR, Pacific Islands Report

I998 A news service provided by the Pacific Islands Development Program, East-West Center, and the Center for Pacific Island Studies, University of Hawai'i at Mānoa, Honolulu. http://pidp.ewc.hawaii.edu/PIReport/

PG, Palau Gazette. Koror. Monthly to I997; two-monthly in 1997; ceased publication 1998.

Shuster, Donald

2000 Political review of Palau in 1998-99. The Contemporary Pacific I2: 217-220.

Taylor, Ian

1998 Africa's Place in the Diplomatic Competition between Beijing and Taipei. Issues and Studies 34 (3): I 26-I 43.

TB, Tia Belau News. Koror. Fortnightly. 